Danuta Urbaniak-Zając, Elżbieta Dubas, Marcin Kafar

\title{
Od redaktorów tomu
}

\section{Wprowadzenie}

W przedkładanym Czytelniczkom i Czytelnikom numerze „NOWIS” koncentrujemy się na zagadnieniu edukacyjnych wymiarów badań biograficznych. Uściślając w ten sposób przedmiot zainteresowań, chcieliśmy nie tylko zawęzić rozległą dziedzinę aktywności badawczej, ale też wyróżnić jej specyfikę właściwą dla pedagogicznego punktu widzenia. Pomimo przyjętego ograniczenia zebrane w zeszycie teksty okazały się być wielorako zróżnicowane. Za główną przyczynę takiego stanu rzeczy odpowiada niejednorodne rozumienie przez nas jako redaktorów tomu samego pojęcia edukacji oraz - na innym poziomie - badań biograficznych (ich przedmiotu, celu, narzędzi metodycznych itp.). Podpierając się tą świadomością, każdy z nas zaprosił do przygotowania artykułu Autorki i Autorów należących do określonej - mniej czy bardziej spójnej - wspólnoty myślowej, w której sam się sytuuje.

Jeden z kłopotów wynikających z zarysowanej sytuacji wiązał się z koniecznością znalezienia odpowiedniej formy tematyczno-argumentacyjnej nadającej się na wstęp do publikacji. Intensywnie zastanawialiśmy się w zespole redakcyjnym, czy lepszym posunięciem będzie poszukiwanie na tę okoliczność obarczonych sporym ryzykiem przedwczesności uspójnień i generalizacji, czy też wybór powinien paść na inne rozwiązanie. Ostatecznie zdecydowaliśmy, iż słowo Od redaktorów tomu posłuży nie tyle prostemu przedstawieniu jego zawartości (wszak każdy artykuł poprzedza streszczenie), co zamieni się w próbę przynajmniej częściowej problematyzacji edukacyjnych wymiarów badań biograficznych. Owa problematyzacja dokonana została przy uwzględnieniu potencjału odmiennych perspektyw poznawczych warunkowanych wskazywanym wyżej biograficzno-naukowym milieu redaktorek i redaktora. Elżbieta Dubas przyjęła perspektywę dyscyplinarną: scharakteryzowała edukacyjny wymiar badań biograficznych w ujęciu andragogicznym. (Gdyby podążyć tym tropem, można by się starać rekonstruować badania biograficzne w ujęciu pedagogiki społecznej, pedagogiki resocjalizacyjnej czy antropologii. Należy przypuszczać, iż trudno byłoby zachować w tym wypadku rozłączność ujęć, dałoby się to osiągnąć jedynie w wyniku ustaleń terminologicznych.) Danuta Urbaniak-Zając spojrzała na zebrane artykuły, skupiając się na ich 
empirycznym wymiarze i w tym kontekście zapytała o profil materiału będącego przedmiotem analiz poszczególnych Autorek oraz Autorów. To pytanie zakłada możliwość odróżnienia badań empirycznych od innych typów poznawania i doświadczania świata; niektóre z przedłożonych tekstów, zwłaszcza odwołujące się do badań nazywanych auto/biograficznymi (tutaj w znaczeniu: bazujących na podejściu refleksywnym), podważają tę możliwość. Przedstawicielem badań auto/biograficznych w zespole redakcyjnym jest Marcin Kafar, którego wypowiedź, z racji na jej objętość, jak i zakres zagadnień przybliżających właściwe mu podejście, postanowiliśmy przenieść do działu „Dyskusje, polemiki”. Tym samym układ zaprezentowanych wypowiedzi redaktorskich tworzy zgodną z duchem zrealizowanego przedsięwzięcia klamry - domykającą (w postaci artykułu Marcina Kafara zatytułowanego Zyskiwanie samowiedzy poznawczej jako proces edukacyjny) i otwierającą (na nią składają się z kolei stanowiące dalsze partie Od redaktorów tomu teksty Elżbiety Dubas (Edukacyjny wymiar badań biograficznych $w$ ujęciu andragogicznym) oraz Danuty Urbaniak-Zając (Empiryczny wymiar badań biograficznych)).

\section{Edukacyjny wymiar badań biograficznych w ujęciu andragogicznym} (Elżbieta Dubas)

Kilka tekstów zawartych w tym tomie ukazuje podejście badawcze realizowane przez współczesnych badaczy andragogów. Warto zwrócić uwagę na jego specyfikę - pewną odmienność w stosunku np. do podejścia antropologiczno-etnograficznego, również prezentowanego w tym tomie. Odmienność nie wyklucza jednak obecności punktów wspólnych, a nade wszystko podobnych wątpliwości i trudności związanych z filozofią takich badań, ich realizacją oraz wynikami teoriopoznawczymi. Badania biograficzne stanowią domenę poszukiwań przedstawicieli nauk o człowieku, w tym w szczególności nauk społecznych i humanistycznych. Do nich zaliczamy także andragogikę uprawianą jako normatywna subdyscyplina pedagogiczna albo opisowa interdyscyplinarna nauka o procesach edukacji człowieka dorosłego. Człowiek i jego biografia stanowią tu przedmiot badań, którego rozpoznawanie pozwala więcej wiedzieć o ludzkiej kondycji. Badanie biografii odsłania nowe lub mało znane zakresy wiedzy o człowieku, w sensie jednostkowym i gatunkowym. Badania biograficzne w polskiej andragogice współcześnie realizowane są z wykorzystaniem różnych założeń teoretyczno-metodologicznych adaptowanych z zagranicy, poczynając od uznania jako szczególnie inspirującego pionierskiego dorobku socjologicznej Szkoły Chicagowskiej z lat 20. XX w.; konteksty historycznego rozwoju tzw. metody biograficznej i jej zastosowania w polskich i zagranicznych badaniach andragogicznych można w tym numerze odnaleźć w artykule Agnieszki Bron, a w tekście Jutty Ecarius Czytelnik pozna niemieckie doświadczenia badań biograficznych w obszarze nauk o wychowaniu. Należy podkreślić, że polskie 
badania biograficzne realizowane przez andragogów, uprawiane od lat 80 . XX w. w łódzkim środowisku andragogicznym, mają także swój rodzimy rodowód, gdyż wywodzą się z założeń metody indywidualnych przypadków w ujęciu Aleksandra Kamińskiego. 0 badaniach biograficznych, ich złożoności, z uwzględnieniem aspektów metodologicznych i trudności w realizacji takich badań, z perspektywy także osobistych doświadczeń badacza donoszą w tym tomie teksty Agnieszki Bron, Joanny Golonki-Legut i Martyny Pryszmont-Ciesielskiej oraz Elżbiety Dubas.

Należy przyjąć, że specyfika badań biograficznych, realizowanych w andragogice, najogólniej polega na poszukiwaniu i odkrywaniu, wydobywaniu z utajenia edukacyjnego wymiaru biografii, który zasadniczo stanowi o ludzkiej dorosłości, a poprzez to o jakości życia w tym okresie. Badania biograficzne w andragogice w sposób zasadniczy konstruują teorię biograficznego uczenia się, zaproponowaną przez Petera Alheita, co można odczytać w tekstach Golonki-Legut i Pryszmont-Ciesielskiej oraz Dubas.

Punktem wyjścia i zarazem kluczowym ustaleniem dla określenia przedmiotu badań andragogicznych w podejściu biograficznym jest doprecyzowanie znaczenia pojęcia „edukacja”. W dzisiejszej, ponowoczesnej debacie, skoncentrowanej wokół badania biografii, dominuje jak najszersze rozumienie edukacji - jako procesu, który „wykroczył” poza szkołę i poza inne instytucje włączone w mniej lub bardziej sformalizowane kształcenie. Edukacja, w szerokim rozumieniu, obejmuje także procesy niesfomalizowanego i niesystematycznego uczenia się, które odnaleźć można w codzienności, we wszystkich przestrzeniach życiowej aktywności, w trakcie spełniania różnorodnych zadań i ról, zmagania się z wyzwaniami losu. Bywa ono określane jako uczenie się na tle życia, uczenie się „w nurcie życia”. Taka formuła uczenia się już wyraźnie przywołuje biografię; przykładem powiązania codziennego życia, bycia na emeryturze i aktywności zawodowej z kontekstem edukacyjnym jest w tym tomie tekst Agaty Szwech opracowany na postawie dzienników Haliny Semenowicz, propagatorki technik Freneta w Polsce. Związek między życiem, biografią i uczeniem się uwypukla ontologiczno-epistemologiczną istotę człowieczeństwa, ujętą w formule homo biographicus i zarazem homo educantus. Tym, co w swoisty sposób „zatrzymuje” doświadczane przez człowieka życie, jest właśnie biografia rozumiana jako swoisty statyczny zapis, jak i zarazem dynamiczne opisywanie życiowych doświadczeń - znaczących, ważnych, pamiętanych, przypominanych, możliwych do przypomnienia i do rekonstrukcji pozwalającej na odszukanie ich nowych znaczeń, a także ich typologizację dokonywaną z pespektywy badacza, tworzącego teorię naukową. Przykłady typologizacji biograficznych doświadczeń, wywodzących się z ich analizy, można odszukać w tekstach Bron i Dubas. Próbę zaś typologizacji podejść badawczych z wykorzystaniem biografii prezentuje tekst Golonki-Legut i Pryszmont-Ciesielskiej.

Biografia dla andragoga jest wielorako rozumianą przestrzenią uczenia się. Takie podejście można dostrzec w tekście Elżbiety Dubas i Emilii Mazurek. W biografii można odnaleźć doświadczenia sformalizowanej, w tym szkolnej 
edukacji, które konstruują jedną z biografii tematycznych - biografię edukacyjną. W biografii można też odnaleźć pozostałe procesy uczenia się, jakich doświadczał jej posiadacz, w tym także procesy uczenia się „na tle życia”, „w nurcie życia”. Biografia, wreszcie, poprzez namysł i refleksje nad doświadczeniami ujętymi w szczególności w narracji biograficznej staje się przestrzenią pogłębiania świadomości i samoświadomości, uświadamiania tego, co było do tej pory mniej świadome lub całkiem nieuświadomione, odkrywania wiedzy do tej pory utajonej, a która „odkryta” może współuczestniczyć w dalszym procesie dookreślania i modyfikacji tożsamości osoby, dalszej jej formacji i transformacji - by więcej wiedzieć i lepiej rozumieć, a przez to żyć pomyślniej. W tym kontekście można też mówić o uczeniu się z biografii, gdzie przypominana biografia jest swoistym „polem” uczenia się poznawania siebie, ponownej autoformacji i transformacji osobowej (Dubas). Należy też podkreślić ważny nurt rozważań w zakresie badań biograficznych, akcentujący narracyjny aspekt uczenia się dorosłego człowieka jako uczenia się poprzez historie, opowieści, a także spostrzeganie samego procesu uczenia się jako procesu narracyjnego, co skłoniło badaczy do sformułowania teorii narracyjnego uczenia się (Mazurek).

Biograficzne podejście/biograficzna perspektywa w badaniach andragogicznych uwzględnia podmiotowy wymiar uczenia się, co jest naturalną konsekwencją „obdarzenia” człowieka dorosłego podmiotowością. Każda biografia zawiera opis zindywidualizowanego doświadczania życia, subiektywny odbiór doświadczeń życiowych, relacjonowanych wielokrotnie, w zmieniającej się perspektywie czasowej i biograficznej. Podmiotowością obdarzony jest tak posiadacz biografii, jak i badacz biografii, jako obie osoby dorosłe „zespolone” w akcie badania biograficznego. Tak więc badanie biografii jest swoistą sytuacją uczenia się tak dla badanego, jak i badacza. To uczenie się rozpościera się w obrębie ich indywidualnych biografii, ale również ujawnia się w przestrzeni wzajemnego ich przenikania się - konfrontacji i ubogacania. Badacz w podejściu biograficznym określony jest przez jego biografię, tak biografię osobistą, jak i naukową. Pozycjonowanie badacza także obejmuje i ten wymiar. Badany zaś w podejściu biograficznym odzyskuje swoją podmiotowość, a przez to i autoformacyjną potencjalność. Refleksje skoncentrowane wokół tego, kim jest, kim może być badacz biografii można odnaleźć w tym tomie w tekstach Agnieszki Bron, Joanny Golonki-Legut i Martyny Pryszmont-Ciesielskiej oraz Elżbiety Dubas.

Badanie biografii odsłania swoisty proces uczenia się, jakim jest permanentne „uczenie się dorosłości”, rozumiane jako stawanie się bardziej dojrzałym, mimo bycia już dojrzałym w sensie obiektywnym. Badanie biografii przez andragoga włącza się w proces dorosłości zarówno badacza, jak i badanego (Golonka-Legut i Pryszmont-Ciesielska). Poprzez refleksję autobiograficzną badanie biografii może uruchomić bardziej świadomy proces rozwoju ku dorosłości rozumianej jako pełna dojrzałość. Poprzez wielokrotne konstrukcje, rekonstrukcje i modyfikacje tożsamości, w wyniku namysłu nad biografią - Innych bądź własną, człowiek dorosły 
doszukuje się sensu życia, a w szczególności sensu swojego życia. Wędrówka życiowa człowieka i jego biograficzna autorefleksja to permanentne i powiązane ze sobą procesy stawania się w swoim człowieczeństwie. Badanie biografii nie tylko opisuje te procesy, ale także uaktywnia procesy osobistego uczenia się badanego i badacza, sprzyjające radzeniu sobie ze złożonością codziennej ludzkiej egzystencji i stawaniu się kimś więcej niż się aktualnie jest. Uaktywnia osobową kompetencję, zwaną biograficznością, która jest koniecznością dla zaistnienia biograficznego uczenia się (Dubas), sprzyjającego procesowi stawania się dorosłym.

Konkludując, biografia dla badacza-andragoga jest „niezbywalnym” przedmiotem badań. Odnajduje on bowiem w biografii - badanego, a także własnej, procesy uczenia się, które formułowały ich dorosłość. Może także, poprzez refleksyjne odczytywanie biografii, permanentnie uruchamiać nowe procesy edukacyjne, redefiniujące ich tożsamość, w szczególności gdy takie redefinicje są potrzebne, a nawet konieczne dla bardziej pomyślnego funkcjonowania w codzienności.

\section{Empiryczny wymiar badań biograficznych}

(Danuta Urbaniak-Zając)

Pytanie, co stanowi materiał badawczy (pomijam w tym momencie artykuły, które nie odnoszą się do rzeczywistości poza tekstowej), który analizują Autorki i Autorzy artykułów przysłanych do zeszytu poświęconego badaniom biograficznym, może wydać się trywialne tylko wówczas, gdy zadowolimy się odpowiedzią, że stanowi go biografia. W pytaniu o materialny obiekt badań ogniskują się podstawowe kwestie: zarówno sposób ujmowania ich przedmiotu (ustalenia ontologiczne), jak i możliwości jego poznawania (ustalenia epistemologiczne). Dla wielu badaczek i badaczy socjalizowanych w orientacji pozytywistycznej dostrzeżenie jej ograniczeń czy nawet jej porzucenie nie zmienia oczekiwań kierowanych pod adresem materiału badawczego. To od jego właściwości - od odpowiedzi na pytanie, na ile odzwierciedla on empiryczne stany rzeczy - zależy zasadność i poziom ogólności formułowanych twierdzeń. Warto przypomnieć, iż w klasycznym empiryzmie przyjmuje się, że wszelkie twierdzenia naukowe można zasadniczo (nie zawsze bezpośrednio) sprawdzić przez doświadczenie, wykazując ich prawdziwość lub fałszywość. Takie ujęcie empiryzmu poddane zostało jednak wielorakiej krytyce, rozszerzyło się także znaczenie „doświadczenia”, w efekcie czego granice badań empirycznych rozmyły się. Odpowiedź na pytanie, czy przywoływane w artykułach badania biograficzne są badaniami empirycznymi, nie jest wcale oczywista.

W zebranych w tym numerze czasopisma artykułach materialnym przedmiotem analiz badawczych są:

- wywołane przez badaczki (ustne, w jednym przypadku pisemne) wypowiedzi specjalnie wybranych osób;

- dziennik emerytowanej pedagog - znanej w środowisku znawców tematu; 
- opowiadania koleżanki badaczki o chłopcu, którego szkolną sytuację owa koleżanka znała z opowiadań samego chłopca i jego matki;

- fikcja literacka - celowo wybrana powieść (Zabić drozda);

- własne życie autora wypowiedzi;

- własne doświadczenia zawodowe dwojga współdziałających badaczy.

Wywołane - i zapisane - wypowiedzi specjalnie wybranych osób są tym rodzajem materiału, który jest typowy dla badań empirycznych w naukach społecznych. Za najbardziej wartościowe w badaniach biograficznych uznawane są swobodne wypowiedzi uczestników badań. Wprawdzie liczby ich uczestników są zwykle niewielkie (aczkolwiek Bron wspomina o 100 pogłębionych wywiadach), ale sposób ich doboru powinien podlegać określonym rygorom. Postuluje się dobór przypadków kontrastowych albo dobór teoretyczny (zob. Bron, Köhler). Celowo dobierane próby badawcze nie są oczywiście reprezentatywne statystycznie, ale mają oddawać różnorodność doświadczeń, sytuacji, właściwości itp. Formułowane uogólnienia nie mają więc charakteru statystycznego, lecz strukturalny (częstą formą uogólnienia są typologie, zob. Bron; typologiczne opisy przypadków przedstawiła Ostaszewska). Warto też podkreślić, iż w analizach biograficznych, mimo że odnoszą się do indywidualnych losów, zawsze odzwierciedla się kontekst społeczny „na przykład wspólne doświadczenia klasowe, płeć i pochodzenie etniczne” (Bron) i kulturowy. Niektóre metody badań jakościowych stosowane w badaniach biograficznych szczególnie mocno eksponują społeczny wymiar doświadczeń indywidualnych (np. metoda dokumentarna, zob. Köhler). W tak prowadzonych badaniach ich wykonawcy mają świadomość wpływu własnych doświadczeń na proces interpretacji materiału badawczego (zob. Ostaszewska), nie czynią ich jednak przedmiotem szczególnego namysłu. Raczej starają się „trzymać je na wodzy”, zastrzegając się, że interpretacje mogą nie być obiektywne. Przywoływanie „obiektywności” wskazuje na istnienie w myśleniu mającym opierać się na przesłankach interakcjonizmu, kryteriów obowiązujących $\mathrm{w}$ innej orientacji metodologicznej. Wyraźnie to widać, gdy postawimy pytanie, co jest miarą obiektywności w badaniach biograficznych? Można przypuszczać, iż brak obiektywności rozumiany jest jako niekontrolowana jednostronność interpretacji. Ta jednostronność może być ograniczana poprzez triangulację danych (zob. Braches-Chyrek; Golonka-Legut, Pryszmont-Ciesielska) i wielokierunkowość interpretacji.

Wykorzystywanie dziennika jako materialnego przedmiotu analizy należy do klasyki badań biograficznych. Dziennik ma o tyle przewagę nad wypowiedziami autobiograficznymi (ustnymi i pisemnymi), że odzwierciedla zdarzenia, sytuacje itp. tak jak następują po sobie oraz towarzyszące im wówczas interpretacje, oceny, emocje (pisząc, autor nie wie, co wydarzy się później). W badaniach biograficznych ukierunkowanych na odtworzenie życia wybitnych jednostek informacje zawarte $\mathrm{w}$ ich dziennikach zestawiane są (czy też triangulowane) z informacjami z innych źródeł. W takich badaniach dążenie do odsłonięcia tego „jak było naprawdę" stanowi zwykle cel podstawowy. Sytuacja się zmienia, kiedy dziennik jest jedynym 
źródłem - jednym poddawanym interpretacji materiałem empirycznym (zob. Szwech). Co ten materiał ma prezentować, zależy od badacza: czy szuka w nim „faktów” (zdarzeń, osób, działań itp.), czy ważniejsze jest biograficzne znaczenie doświadczeń? Warto pamiętać, że autorka czy autor dziennika nie muszą być świadomi tego znaczenia w momencie pisania, nie mogą więc go wprost przedstawić. Badaczka czy badacz, mając dostęp do całego dziennika, mogą te znaczenia rekonstruować na podstawie śladów pozostawionych w różnych miejscach. Swego rodzaju balastem ograniczającym interpretacje dzienników może być nadmierna obawa badaczki czy badacza przed „subiektywnością” interpretacji, prowadzi to bowiem do ich maksymalnego ograniczenia na rzecz streszczania fragmentów dzienników.

Materiałem empirycznym wykorzystanym przez Iwonę Kabzińską są opowieści koleżanki o problemach szkolnych i rozwojowych syna jej siostrzenicy. A więc podstawą opowieści są doświadczenia konkretnego dziecka i jego najbliższych. Materiałem wykorzystywanym przez innego autora Heinza Sünkera jest powieść - fikcja literacka. Można przypuszczać, że również ona opiera się na doświadczeniach autorki (Harper Lee) i zasłyszanych opowieściach innych ludzi. Tym samym empiryczność źródeł obu tekstów jest podobna: realne wydarzenia stały się przedmiotem opowieści (ustnej albo pisemnej), wykorzystanej następnie przez badaczkę i badacza. W ich artykułach nie ma miejsca na pytanie o zgodność tych opowieści z rzeczywistością, co jest nieodzowne w typowych badaniach empirycznych (różne rodzaje walidacji). Podstawowe podobieństwo między opowieściami koleżanki a powieścią tkwi w funkcji, jaką pełnią one w obu artykułach. Stanowią egzemplifikację problemu znanego autorce i autorowi skądinąd, m.in. z literatury przedmiotu. Przywoływane doświadczenia biograficzne realnej postaci czy postaci fikcyjnych stanowią konkretyzację twierdzeń ogólnych, pozwalają na eksponowanie niuansów. A przede wszystkim wzmacniają perswazyjną siłę wypowiedzi badaczy - oboje opowiadają się za zmianą warunków umożliwiającą pełniejszy rozwój człowieka. W tej perspektywie badawczej uzasadnieniem dla formułowanych twierdzeń nie jest ani częstotliwość występowania danych sytuacji i zachowań, ani zróżnicowanie ich kontekstów, lecz wartości - etyczny wymiar warunków życia i działania.

Jeszcze inna „materia” jest przedmiotem analiz Wojciecha Burszty oraz Izabeli Kamińskiej-Jatczak i Marcina Kafara. Pierwszą wypowiedź charakteryzuje namysł Autora nad własnymi doświadczeniami biograficznymi, w drugiej natomiast uzewnętrzniane doświadczenia indywidualne zestawiane są z doświadczeniami partnerki/partnera dialogu bezpośredniego lub zapośredniczonego poprzez tekst. W tej sytuacji język i kryteria typowych empirycznych badań społecznych przestają być adekwatne. Uzewnętrznienie doświadczeń staje się jednocześnie procesem i efektem ich badania. Badania auto/biograficzne nie pozostawiają wątpliwości, że doświadczenie ujawnia się zawsze w kontekście prezentującej go świadomości. Warto jednak zauważyć, iż z taką sytuacją mamy do czynienia we wszystkich 
badaniach społecznych - doświadczenia ludzi poznajemy wyłącznie poprzez ich relacje o doświadczeniach. Ale... w procesie typowych badań empirycznych te doświadczenia poddawane są różnym „zabiegom”, by odsłonić to, czego nie muszą być świadome relacjonujące je osoby. W badaniach auto/biograficznych nosiciel biografii, osoba ją opowiadająca (choćby sama sobie) oraz poddająca refleksji w usystematyzowanej wypowiedzi stanowią jedność - nie ma zewnętrznego interpretatora. Wydaje się, że nadrzędnym celem prezentowanych w naszym tomie badań auto/biograficznych jest uświadomienie sobie przez badaczy sensu zdarzeń kształtujących ich tożsamość i biografie naukowe. Realizacja takiego celu ma bez wątpienia znaczenie autoedukacyjne, ale od badań oczekuje się także wartości poznawczej. Wydaje się, iż rośnie ona, gdy jednostkowość doświadczeń sytuowana jest w interesujący sposób w ogólniejszym kontekście.

Podsumowując, przyjęcie pozornie technicznej kwestii - specyfiki analizowanego materiału - jako perspektywy spojrzenia na przywoływane w niniejszym tomie badania biograficzne, zwraca uwagę nie tyle na odmienność podejść, co teoretyczne problemy badań biograficznych, które w codziennej praktyce badawczej są pomijane, ponieważ problematyczność przypisuje się raczej innej - niż własna - orientacji metodologicznej. 